\title{
EFFECT OF INCLUDING DRIED DISTILLERS GRAIN WITH SOLUBLE IN GROWING LAMBS DIET ON DIGESTIBILITY, SOME RUMEN PARAMETERS, BLOOD CONSTITUENTS AND PERFORMANCE \\ Gabr, A.A.*; M.M. El-Shinnawy*; Eman H. Makled ${ }^{*}$ and Noha T. H. Tag El-Din** \\ * Animal Prod. Dept., Fac. Agric., Mansoura University, Egypt. \\ ** Animal Prod. Dept., Fac. Agric., Damietta, Mansoura Univ., Egypt.
}

\begin{abstract}
The present study was conducted to determine the effects of dried distillers grains with soluble (DDGS) inclusion in lamb fattening diets replacing (partially or totally) soybean meal (SBM) as a protein source and corn as an energy source on growth performance, digestibility, rumen liquor traits, some blood plasma constituents, and economic efficiency. Twenty $3 / 4$ Romanov $\times 1 / 4$ Rahmani male lambs at about three months of age were divided randomly into four experimental groups with average live weight $(17.7 \pm 0.7 \mathrm{~kg})$. Each lamb's group was randomly assigned for one of four experimental diets and was fed in group feeding in mash form. The complete diets comprised $40 \%$ clover hay $(\mathrm{CH})$ and $60 \%$ concentrate feed mixture (CFM) containing 0\% DDGS (T1, control), 10\% DDGS (T2), 15\% DDGS (T3) or $20 \%$ DDGS (T4). The main results showed that the DDGS contained $29 \% \mathrm{CP}, 10 \% \mathrm{EE}$, $10 \%$ CF, 46\% NFE ,5\% ash, 18\% ADF, 44\% NDF, 26\% hemi-cellulose, $14 \%$ cellulose, $4.1 \%$ ADL and $12 \%$ NFC. All the total mixed diets had nearly equal values for chemical nutrients except that of NFE content. The inclusion of DDGS in lamb's diets at 10, 15 and $20 \%$ resulted in better digestion coefficients of all nutrients and nutritive value as TDN and DCP\% in comparison with the control group. The same trend was found also in the concentrations of energy (DE, ME and NE Mcal $/ \mathrm{kg}$ ). Ruminal $\mathrm{pH}$ values and $\mathrm{NH}_{3}-\mathrm{N}$ were slightly changed among treatments. However, VFA's concentrations (meq/100ml) was gradually increased $(P \geq 0.05)$ with elevating the DDGS level in the diets. The lambs of $\mathrm{T} 1$ and $\mathrm{T} 2$ recorded nearly similar values of average daily gain; ADG (163.1 and 161.3g), however, those of T3 and T4 had higher ADG (181.0 and $192.0 \mathrm{~g}$ ) than the control by about 11.0 and $17.7 \%$, respectively. The intake of TDN and DCP were gradually increased with elevating DDGS level in the diet from 0 up to $20 \%$. The DDGS inclusion in lamb diets did not show positive effects concerning feed conversion as $\mathrm{g}$ TDN or $\mathrm{g} \mathrm{DCP} / \mathrm{g}$ gain, meanwhile, the lambs of T3 and T4 recorded better values of DM conversion than the control (T1) by about 7.1 and $9.8 \%$, respectively. Economic efficiency was gradually improved with elevating DDGS level in the diet where it was better for T2, T3 and T4 groups than the control (T1) by about $11.0,34.6$ and $45.6 \%$, respectively. It may be concluded that in general, the inclusion of DDGS instead of corn and SBM at any level resulted in better performance, feed utilization and economic efficiency.
\end{abstract}

Keywords: DDGS, lambs, digestibility, nutritive value, rumen fermentation, blood constituents, feed cost, economic efficiency.

\section{INTRODUCTION}

The prices of all animal feedstuffs in Egypt are highly increased especially for corn and soybean meal to be 2-3 folds during the last five years. The cost of feeding cattle is rising steadily because of increased 
Gabr, A.A. et al.

forage and grain costs (NASS, 2008). It may be economical to partially replace forage and/or grains with by-products. Therefore, by-products from the ethanol industry are gaining popularity as feedstuffs in the cattle industry of their availability, nutritive value and cost (Leupp, 2008).

The dried distiller's grain with soluble (DDGS) is recently imported to the Egyptian market as a new feed ingredient for animal feeding. This material is a strange ingredient for animal and poultry keepers; therefore, it is not accepted well from them irrespective of its nutritional and economic values.

A primary ethanol industry co-product; DDGS, is an excellent source of energy and protein for beef cattle and sheep (Lardy, 2003). Some information is available on feeding DDGS to cattle (Pederson et al., 2007); however, limited research has been done on rabbits (Gabr et al., 2008), sheep or goats (McEachern, 2008). The value of DDGS will increase if it can be used to replace all of or a portion of the crude protein content in growing rations for sheep and goats, which is normally occupied by cottonseed meal, soybean meal, or alfalfa meal. Energy constituents of the rations could also be altered from Milo or corn to DDGS if the desired effects are achieved by the replacement. Little research has evaluated the inclusion of DDGS as a replacement for concentrate in lamb finishing rations (Schauer et al., 2008). It was reported that DDGS could be included at levels up to $22.5 \%$ of a finishing ration with no negative effects on lamb performance or carcass traits (Schauer et al., 2008). The main objectives of this study were to determine the effects of DDGS inclusion in growing lamb diets replacing (partially or totally) soybean meal (SBM) as a protein source and corn as an energy source on their growth performance, digestibility, rumen parameters, some blood plasma constituents and economic efficiency.

\section{MATERIALS AND METHODS}

This study was conducted at the Animal Production Unit, Research and Agricultural Experiments Center, Faculty of Agriculture, Mansoura University from July 2007 to January 2008.

Twenty $3 / 4$ Romanov $\times 1 / 4$ Rahmani male lambs at about three months of age were divided randomly into four experimental groups, five animals each. Each group was housed in a separate well-ventilated pen. All groups had nearly equal average live weight $(17.7 \pm 0.7 \mathrm{~kg})$. Each lamb's group was randomly assigned to one of four experimental diets and was fed in group feeding for 24 weeks. All total mixed diets were formulated to cover the nutritional requirements for growing lambs that grow about $200 \mathrm{~g}$ daily according to NRC (1985). The total mixed diets contained $40 \%$ good quality clover hay $(\mathrm{CH})$ from the $3^{\text {rd }}$ cut as well as $60 \%$ concentrates feed mixture (CFM). The CFM contained DDGS at $0.0 \%\left(\mathrm{CFM}_{1}\right), 10 \%\left(\mathrm{CFM}_{2}\right), 15 \%$ $\left(\mathrm{CFM}_{3}\right)$ or $20 \%\left(\mathrm{CFM}_{4}\right)$. The composition of the experimental CFM and total mixed diets are presented in Table 1. Daily amount of total mixed feeds was offered for animals in two equal meals at 8 a.m. and 3 p.m. in mash form. Clean drinking water was available all the time. 
Table 1: Composition of concentrate feed mixtures (CFM) and total mixed diets.

\begin{tabular}{|c|c|c|c|c|c|c|c|c|}
\hline $\begin{array}{c}\text { Ingredients } \\
(\%)\end{array}$ & \multicolumn{4}{|c|}{ CFM $^{*}$} & \multicolumn{4}{c|}{ Total mixed diets } \\
\cline { 2 - 9 } & $\mathbf{1}$ & $\mathbf{2}$ & $\mathbf{3}$ & $\mathbf{4}$ & $\mathbf{T 1}$ & $\mathbf{T 2}$ & $\mathbf{T 3}$ & T4 \\
\hline Yellow corn & 40.0 & 35.0 & 32.5 & 30.0 & 24.0 & 21.0 & 19.5 & 18.0 \\
\hline SBM (44\%) & 10.0 & 5.0 & 2.5 & 0.0 & 6.0 & 3.0 & 1.5 & 0.0 \\
\hline DDGS & 0.0 & 10.0 & 15.0 & 20.0 & 0.0 & 6.0 & 9.0 & 12.0 \\
\hline Wheat bran & 28.0 & 28.0 & 28.0 & 28.0 & 16.8 & 16.8 & 16.8 & 16.8 \\
\hline Rice bran & 15.0 & 15.0 & 15.0 & 15.0 & 9.0 & 9.0 & 9.0 & 9.0 \\
\hline Molasses & 5.0 & 5.0 & 5.0 & 5.0 & 3.0 & 3.0 & 3.0 & 3.0 \\
\hline Lime stone & 1.0 & 1.0 & 1.0 & 1.0 & 0.6 & 0.6 & 0.6 & 0.6 \\
\hline Salt & 1.0 & 1.0 & 1.0 & 1.0 & 0.6 & 0.6 & 0.6 & 0.6 \\
\hline CH $^{\star *}$ & - & - & - & - & 40 & 40 & 40 & 40 \\
\hline Total & 100 & 100 & 100 & 100 & 100 & 100 & 100 & 100 \\
\hline
\end{tabular}

$\mathrm{CFM}_{1}$ : contained $0 \%$ DDGS, CFM ${ }_{2}$ : contained $10 \%$ DDGS, $\mathrm{CFM}_{3}$ : contained $15 \%$ DDGS and $\mathrm{CFM}_{4}$ : contained $20 \%$ DDGS.

${ }^{\star *} \mathrm{CH}$ : clover hay.

Animals were weighed bi-weekly before the morning feeding. Daily amount of total mixed feeds were changed bi-weekly according to live weight change. The digestibility trials were conducted at the end of the feeding trial. It consisted of 14 days as an adaptation period to the metabolic cages and 5 days as a collection period. Rumen liquor samples were collected at the end of the digestibility trial using a rubber stomach tube before feeding $(0 \mathrm{hr})$ and at 3 and 6 hrs post morning feeding. Rumen liquor samples were strained through four layers of cheese cloth at each sampling time for immediate determination of rumen $\mathrm{pH}$ with Orion 680 digital $\mathrm{pH}$ meter. Ammonia-N was determined in rumen liquor according to Conway (1962). Total volatile fatty acids concentrations were determined in rumen liquor according to Warner (1964).

Chemical analyses of total mixed diets, clover hay $(\mathrm{CH})$, DDGS and feces were carried out according to A.O.A.C. (1990). Fiber fractions were determined after Goering and Van Soest (1970).

The gross energy (GE) values of complete experimental diets were calculated after MAFF (1975) as follows: The gross energy (GE) (MJ/kg DM) $=0.0226 \mathrm{CP}+0.0407 \mathrm{EE}+0.0192 \mathrm{CF}+0.0177 \mathrm{NFE}$.

The digestible energy (DE) was calculated as:

DE $(\mathrm{Mcal} / \mathrm{kg} \mathrm{DM})=$ TDN $(\%) \times 0.04409(\mathrm{NRC}, 1985)$.

The metabolizable energy (ME) was calculated as:

$\mathrm{ME}($ Mcal $/ \mathrm{kg} \mathrm{DM})=0.82 \times \mathrm{DE}(\mathrm{Mcal} / \mathrm{kg} \mathrm{DM})$ according to NRC (1985). Metabolizability was also calculated as ME / GE (\%) (Abbott and Maxwell, 2002).

Net energy was calculated according to NRC (1998) as follows:

$\mathrm{NE}(\mathrm{Mcal} / \mathrm{kg} \mathrm{DM})=0.025(\mathrm{TDN} \%)-0.12$.

$\mathrm{NFC}=100-\mathrm{CP}-\mathrm{EE}-$ Ash - NDF (Calsamiglia et al., 1995)

Where NFC $=$ Non fiber carbohydrates

At the end of the feeding trial, blood samples were collected before morning feeding and after 3 hrs post-feeding from jugular vein in heparinized test tubes, thereafter; they were immediately centrifuged at $4000 \mathrm{rpm}$ for 15 
Gabr, A.A. et al.

minutes to separate plasma. Plasma constituents' concentrations were determined according to Armstrong and Carr (1964) for total protein (TP), Doumas et al. (1971) for albumen (A), Reitman and Frankel (1957) for AST and ALT and Bartels (1971) for creatinine (Cr). Globulin (G) was calculated by the difference between TP and $A$. The $A / G$ ratio was also calculated. Statistical analysis of data was performed using SAS (2000), and the significant differences among means were detected by Duncan's multiple range test (Duncan, 1955).

\section{RESULTS AND DISCUSSION}

Results of the chemical analyses of DDGS, $\mathrm{CH}$ and total mixed diets are presented in Table 2. The DDGS contained 29.0\% CP, $10.0 \% \mathrm{EE}, 10.0 \%$ CF, $46.0 \%$ NFE and $5.0 \%$ ash. The fiber fractions in DDGS were $18.0 \%$ ADF and $44.0 \% \mathrm{NDF}, 26.0 \%$ hemi-cellulose, $14.0 \%$ cellulose, $4.1 \% \mathrm{ADL}$ and $12.0 \%$ NFC. Similar values have been reported in NRC (2001) and Spiehs et al. (2002), but CP\% was higher than the value $26.22 \%$ given by Gabr et al (2008). The clover hay $(\mathrm{CH}$ ) contained (on DM basis) $17 \% \mathrm{CP}, 3.0 \% \mathrm{EE}$, $26 \%$ CF, $43 \%$ NFE, $11 \%$ ash, 35\% ADF, $45 \%$ NDF, $10 \%$ ADL, $10 \%$ hemicellulose, $25 \%$ cellulose and $24 \%$ NFC.

Table 2: Chemical analysis (\%) of total mixed diets, clover hay $(\mathrm{CH})$ and DDGS (on DM basis).

\begin{tabular}{|c|c|c|c|c|c|c|}
\hline \multirow{2}{*}{ Ingred. $(\%)$} & \multicolumn{7}{|c|}{ Total mixed diets } & \multirow{2}{*}{ CH } & \multirow{2}{*}{ DDGS } \\
\cline { 2 - 5 } & T1 & T2 & T3 & T4 & & \\
\hline OM & 92.2 & 92.2 & 92.2 & 92.2 & 89.0 & 95.0 \\
\hline CP & 15.9 & 16.0 & 16.1 & 16.2 & 17.0 & 29.0 \\
\hline EE & 4.4 & 4.9 & 5.1 & 5.3 & 3.0 & 10.0 \\
\hline CF & 14.5 & 14.8 & 15.0 & 15.2 & 26.0 & 10.0 \\
\hline NFE & 57.5 & 56.5 & 56.0 & 55.5 & 43.0 & 46.0 \\
\hline ASH & 7.8 & 7.8 & 7.8 & 7.8 & 11.0 & 5.0 \\
\hline Fiber fractions \%, on DM basis : & 19.5 & 20.2 & 20.5 & 20.9 & 35.0 & 18.0 \\
\hline ADF & 32.1 & 34.0 & 35.0 & 36.0 & 45.0 & 44.0 \\
\hline NDF & 14.2 & 14.7 & 15.0 & 15.2 & 10.0 & 26.0 \\
\hline ADL & 12.6 & 13.9 & 14.5 & 15.1 & 10.0 & 14.0 \\
\hline Hemicell. & 5.3 & 5.5 & 5.5 & 5.6 & 25.0 & 4.1 \\
\hline Cellul. & 39.8 & 37.3 & 36.0 & 34.7 & 24.0 & 12.0 \\
\hline NFC & \multicolumn{7}{|l}{}
\end{tabular}

All the total mixed diets had approximately equal values for chemical nutrients, except that of NFE content. The fiber fractions; NDF and cellulose were positively correlated with elevating DDGS level in the diets. The ADF, hemi-cellulose and ADL were slightly increased with elevating the DDGS level in the diets. The NFC was decreased gradually as DDGS level increased in the diets from $39.8 \%$ (T1) to $34.7 \%$ (T4).

The dry matter intakes (DMI) of lambs throughout the digestibility trials are shown in Table 3. The DMI as $\mathrm{g} / \mathrm{h} / \mathrm{d}$ or $\mathrm{g} / \mathrm{kg} \mathrm{BW}{ }^{0.75}$ were increased gradually with increasing DDGS level in the diets. The lambs fed $20 \%$ DDGS- 
contained diet $(T 4)$ consumed significantly $(P \geq 0.05)$ more DM $(g / h / d)$ than the other groups.

Table 3: Digestion coefficients* $(\%)$ of nutrients, nutritive values and energy concentration as affected by DDGS level in the tesed diets.

\begin{tabular}{|c|c|c|c|c|}
\hline \multirow{2}{*}{ Items } & \multicolumn{4}{|c|}{ Total mixed diets } \\
\hline & T1 & T2 & T3 & T4 \\
\hline \multicolumn{5}{|c|}{ Dry matter intake : } \\
\hline \multirow{2}{*}{$\begin{array}{l}\mathrm{g} / \mathrm{h} / \mathrm{d} \\
\mathrm{g} / \mathrm{kg} \mathrm{BW} W^{0.75}\end{array}$} & $1091.8 \pm 47.8$ & $1153.8 \pm 58.6$ & $1203.9 \pm 35.2$ & $1278.2 \pm 126.4$ \\
\hline & $64.5 \pm 1.8$ & $65.4 \pm 1.2$ & $66.4 \pm 2.3$ & $67.1 \pm 1.2$ \\
\hline LBW, kg & \multicolumn{2}{|l|}{$43.5 \pm 1.9$} & $47.7 \pm 1.8$ & $51.0 \pm 3.5$ \\
\hline \multicolumn{5}{|c|}{ Nutrients digestibility, $\%$} \\
\hline DM & $63.5 \pm 4.0$ & $71.7 \pm 1.9$ & $68.5 \pm 3.0$ & $71.3 \pm 5.6$ \\
\hline $\mathrm{OM}$ & $67.3 \pm 3.1$ & $73.0 \pm 1.9$ & $72.0 \pm 1.0$ & $74.9 \pm 5.2$ \\
\hline $\mathrm{CP}$ & $69.1 \pm 4.1^{b}$ & $77.0 \pm 0.5^{\mathrm{a}}$ & $74.2 \pm 2.7^{\mathrm{a}}$ & $78.0 \pm 1.1^{\mathrm{a}}$ \\
\hline CF & $53.9 \pm 5.8^{b}$ & $65.5 \pm 2.1^{\mathrm{a}}$ & $61.3 \pm 4.9^{\mathrm{ab}}$ & $64.9 \pm 4.5^{\mathrm{a}}$ \\
\hline EE & $82.8 \pm 1.7$ & $87.0 \pm 1.2$ & $85.9 \pm 2.7$ & $86.8 \pm 2.0$ \\
\hline NFE & $68.9 \pm 2.2$ & $72.6 \pm 2.5$ & $74.8 \pm 3.6$ & $75.5 \pm 8.1$ \\
\hline GE & $70.7 \pm 1.2^{b}$ & $76.1 \pm 0.8^{b}$ & $74.4 \pm 2.5^{\mathrm{a}}$ & $76.9 \pm 2.5^{\mathrm{a}}$ \\
\hline \multicolumn{5}{|c|}{ Fiber fractions, $\%$} \\
\hline NDF & $60.1 \pm 7.2$ & $63.0 \pm 6.3$ & $66.9 \pm 6.2$ & $69.9 \pm 6.9$ \\
\hline ADF & $65.8 \pm 2.0^{\mathrm{b}}$ & $70.0 \pm 1.3^{\mathrm{a}}$ & $70.2 \pm 2.0^{\mathrm{a}}$ & $72.1 \pm 2.9^{\mathrm{a}}$ \\
\hline ADL & $32.4 \pm 1.3$ & $33.1 \pm 3.6$ & $35.9 \pm 5.4$ & $40.3 \pm 12.3$ \\
\hline Cellulose & $78.2 \pm 1.9$ & $83.6 \pm 0.7$ & $82.9 \pm 0.7$ & $83.8 \pm 2.3$ \\
\hline Hemicell. & $51.3 \pm 9.0$ & $52.9 \pm 7.8$ & $62.3 \pm 7.1$ & $66.9 \pm 7.2$ \\
\hline NFC & $70.3 \pm 0.9$ & $78.6 \pm 1.2$ & $73.9 \pm 4.3$ & $76.7 \pm 8.2$ \\
\hline \multicolumn{5}{|c|}{ Nutritive values: } \\
\hline TDN \% & $66.7 \pm 1.7$ & $72.6 \pm 1.0$ & $72.8 \pm 1.4$ & $74.7 \pm 3.1$ \\
\hline DCP \% & $11.0 \pm 0.4^{b}$ & $12.4 \pm 0.1^{\mathrm{a}}$ & $11.9 \pm 0.3^{\text {ab }}$ & $12.6 \pm 0.1^{\mathrm{a}}$ \\
\hline NFC/DCP & 3.62 & 3.00 & 3.00 & 2.75 \\
\hline \multicolumn{5}{|c|}{ Energy concentration $* *$} \\
\hline $\mathrm{GE}$ & 4.385 & 4.410 & 4.423 & 4.436 \\
\hline $\mathrm{DE}$ & 2.940 & 3.200 & 3.209 & 3.294 \\
\hline $\mathrm{ME}$ & 2.412 & 2.625 & 2.632 & 2.701 \\
\hline NE & 1.548 & 1.695 & 1.700 & 1.748 \\
\hline \multicolumn{5}{|c|}{ Metabolisability \% } \\
\hline ME/GE & 54.9 & 59.4 & 59.5 & 60.8 \\
\hline \multicolumn{4}{|c|}{ Efficiency of ME utilization \% } & \\
\hline \begin{tabular}{|l}
$\mathrm{NE} / \mathrm{ME}$ \\
\end{tabular} & 64.2 & 64.6 & 64.6 & 64.7 \\
\hline
\end{tabular}

** Mcal/kg DM

The inclusion of DDGS in lamb's diets at 10, 15 and $20 \%$ resulted in better digestion coefficients of all nutrients in comparison to the control group. The improvements in digestibility were significant $(P \geq 0.05)$ for $C P, C F, A D F$ and GE. The obtained results show (on the average) that the lambs of T4 had the best digestibility followed by those of T2, T3 and then T1 in a descending order. These results are in agreement with those reported by Leupp (2008), Leupp et al. (2006 \& 2009). The nutritive values and energy concentrations of 
Gabr, A.A. et al.

the experimental diets are shown in Table 3. The TDN and DCP\% were gradually increased with elevating the DDGS level in the diets. The differences in DCP\% due to DDGS level were significant $((P \geq 0.05)$.

The NFC/DCP ratio was 3.62, 3.0, 3.0 and 2.75 for T1, T2, T3 and T4, respectively. The lambs in T2, T3 and T4 had the lowest ratios of NFC/DCP indicating to the highest protein utilization in these groups, compared with the control one.

Although the four mixed diets had approximately equal values of GE, the DE and ME concentrations, the DDGS-contained diets (10, 15 and $20 \%$ ) were higher in previous parameters than the control (T1) by about 8.8, 9.1 and $12.0 \%$, respectively. The corresponding superiority of NE content of DDGS-contained diets than the control was $9.5,9.9$ and $12.9 \%$, respectively. The metabolizability (ME/GE) of DDGS-contained diets was better than that of the control by about $9.1 \%$ (on the average). However, the efficiency of ME utilization was not affected greatly by DDGS inclusion in diets. In this respect, Stock et al. (2000) suggested that the improved energy responses from feeding DDGS may be due to additional un-degradable intake protein (UIP), higher fat content, or potential for reducing acidosis.

Data of rumen parameters are shown in Table 4. Ruminal $\mathrm{pH}$ values were slightly changed among treatments where it ranged from 6.34 (T4) to 6.5 (T2). The same trend was found also for $\mathrm{NH}_{3}-\mathrm{N}(\mathrm{mg} / \mathrm{dl})$ where it varied between 11.6 (T3) and 12.7 (T1). However, VFA's concentrations (meq/100ml) was gradually increased $(P \geq 0.05)$ with elevating the DDGS level in the diets.

Table 4: Effect of DDGS level and sampling time on rumen liquor traits*

\begin{tabular}{|c|c|c|c|c|}
\hline \multirow{2}{*}{ DDGS level } & \multicolumn{4}{|c|}{ Sampling time post-feeding (hrs.) } \\
\hline & $\mathbf{0}$ & 3 & 6 & Average \\
\hline \multicolumn{5}{|l|}{ pH value: } \\
\hline \multirow{5}{*}{$\begin{array}{c}\text { T1 Control } \\
\text { T2 10\% } \\
\text { T3 } 15 \% \\
\text { T4 } 20 \% \\
\text { Average }\end{array}$} & $6.99 \pm 0.14$ & $5.85 \pm 0.03$ & $6.34 \pm 0.01$ & $6.39 \pm 0.75$ \\
\hline & $7.34 \pm 0.19$ & $5.61 \pm 0.05$ & $6.54 \pm 0.23$ & $6.50 \pm 0.89$ \\
\hline & $7.15 \pm 0.07$ & $5.55 \pm 0.05$ & $6.36 \pm 0.10$ & $6.35 \pm 0.83$ \\
\hline & $7.04 \pm 0.23$ & $5.90 \pm 0.13$ & $6.10 \pm 0.12$ & $6.34 \pm 0.58$ \\
\hline & $7.13 \pm 0.20^{\mathrm{a}}$ & $5.73 \pm 0.24^{\mathrm{b}}$ & $6.35 \pm 0.19^{a b}$ & \\
\hline \multicolumn{5}{|c|}{ NH3-N (mg/100 ml) } \\
\hline \multirow{5}{*}{\begin{tabular}{|c|} 
T1 Control \\
T2 $10 \%$ \\
T3 $15 \%$ \\
T4 $20 \%$ \\
Average
\end{tabular}} & $9.6 \pm 0.9$ & $15.9 \pm 2.0$ & $12.1 \pm 1.0$ & $12.5 \pm 1.2$ \\
\hline & $10.7 \pm 1.7$ & $15.4 \pm 2.1$ & $11.9 \pm 1.8$ & $12.7 \pm 1.2$ \\
\hline & $9.1 \pm 0.4$ & $13.8 \pm 1.8$ & $11.9 \pm 1.1$ & $11.6 \pm 0.9$ \\
\hline & $10.3 \pm 0.6$ & $14.2 \pm 1.7$ & $12.1 \pm 1.2$ & $12.2 \pm 0.9$ \\
\hline & $9.9 \pm 0.5^{\mathrm{C}}$ & $14.8 \pm 0.9^{A}$ & $12.0 \pm 0.6^{\mathrm{B}}$ & \\
\hline \multicolumn{5}{|c|}{ TVFA's m.eq/100 ml } \\
\hline \multirow{5}{*}{$\begin{array}{c}\text { T1 Control } \\
\text { T2 } 10 \% \\
\text { T3 } 15 \% \\
\text { T4 } 20 \% \\
\text { Average }\end{array}$} & $7.91 \pm 0.29$ & $10.15 \pm 0.38$ & $9.48 \pm 0.35$ & $9.18 \pm 1.12^{b}$ \\
\hline & $8.46 \pm 0.23$ & $10.52 \pm 0.23$ & $9.95 \pm 0.25$ & $9.64 \pm 0.98^{\mathrm{ab}}$ \\
\hline & $8.99 \pm 0.35$ & $11.62 \pm 0.34$ & $10.48 \pm 0.18$ & $10.36 \pm 1.23^{\mathrm{a}}$ \\
\hline & $9.11 \pm 0.28$ & $12.81 \pm 0.29$ & $10.75 \pm 0.25$ & $10.89 \pm 1.66^{\mathrm{a}}$ \\
\hline & $8.62 \pm 0.66^{c}$ & $11.28 \pm 1.18^{\mathrm{a}}$ & $10.17 \pm 0.6^{b}$ & \\
\hline
\end{tabular}

* Means within each row or within each column within each trait having similar letter are not significantly different at $P \geq 0.05$. 
It was observed that the lambs fed DDGS-contained diets (15 and 20\% DDGS) had higher $(P \geq 0.05)$ values of ruminal VFA's concentration than the control group.

The sampling time had significant $(P \geq 0.05)$ effects on ruminal parameters. The $\mathrm{pH}$ value was decreased after $3 \mathrm{hrs}$ post-feeding (5.73) compared with that obtained immediately before feeding (7.13), then it increased again to reach 6.35 after $6 \mathrm{hrs}$ post-feeding. On the other hand, the ruminal $\mathrm{NH}_{3}-\mathrm{N}$ and VFA's concentrations were increased after $3 \mathrm{hrs}$ post feeding compared with those before feeding and then slightly decreased after $6 \mathrm{hrs}$ post-feeding. In this field, May (2008) observed decreases in ruminal ammonia concentration when feeding distillers dried grains to feedlot cattle. Mean ruminal $\mathrm{pH}$ of feedlot cattle fed high-grain diets is usually between 5.6 and 6.2 (Schwartzkopf-Genswein et al., 2003). May et al. (2007) reported that ruminal $\mathrm{pH}$ was lower in cattle fed $25 \%$ of DM DDGS compared to cattle fed no DDGS as a partial replacement of steam-flaked corn (SFC) or dry rolled corn (DRC) in finishing diets. Steers fed 25\% DDGS also had lower ruminal ammonia concentrations than steers fed 0\% DDGS during the first 10 hours after feeding. Leupp (2008) found that the DDGS level in the diet had significant effects on ruminal $\mathrm{pH}$ and VFA concentration.

As for blood plasma constituents (Table 5), no significant differences among treatments were observed except that of activity of ALT (on average). Increasing level of DDGS in diet of lambs increased TP concentration, being the highest in T4, modest in T3 and the lowest in T2, which may indicate the beneficial effect of increasing plasma TP concentration by increasing level of DDGS up to $20 \%$ in diets of lambs. Kaneko (1989) reported that normal range of TP in sheep to be 6.0-7.9 mg/dl, however, Jawasreh et al. (2010) showed that it was $5.9-7.8 \mathrm{mg} / \mathrm{dl}$.

Albumin concentration was higher in lambs fed different DDGS levels than in the control treatment. Such trend of increase in albumin concentration by dietary treatment was mainly associated with the observed changes in concentration of TP. The normal range of globulin was reported by Jawasreh et al. (2010) to be $3.2-5.0 \mathrm{~g} / \mathrm{dl}$. There was a tendency of higher values of globulin concentration in lambs fed 10 and 20\% DDGS and lower values in those fed 15\% DDGS than in the control treatment (Table 5), although there was a tendency of lower A/G ratio in lambs fed 10 and 20\% DDGS (2.29 and $2.03)$ and higher ratio in those fed $15 \%$ DDGS (2.58) than in the control treatment (2.46).

Generally, the effect of corn and SBM replacement by DDGS in diets of lambs up to $20 \%$ revealed slight improvement in term of increased concentration of TP and their fraction in blood plasma within the normal range (Yousef, 2005), which may indicate the save usage of DDGS in diet of lambs up to $20 \%$ without any adverse effects on protein metabolism. Similar trend have been reported by Saleh et al. (2008). In addition, El-Ashry et al. (1996) concluded that the higher albumin concentration in the blood serum reflects no pathological disorders in liver. Also, Kazemi et al. (2009) found no significant changes in serum albumin between treatments contained ensiled barley distillers grains (BG) replacing corn silage at various levels in cow rations. 
Gabr, A.A. et al.

Table 5: Blood plasma constituents* $(X \pm S . E)$ as affected by DDGS level in the diets and sampling time.

\begin{tabular}{|c|c|c|c|c|c|}
\hline \multirow{2}{*}{$\begin{array}{l}\text { Sampling } \\
\text { time, } h\end{array}$} & \multicolumn{4}{|c|}{ Total mixed diets } & \multirow{2}{*}{ average } \\
\hline & T1 & T2 & T3 & T4 & \\
\hline \multicolumn{6}{|c|}{ Total protein (g/dl) } \\
\hline 0 & $7.33 \pm 0.7$ & $7.54 \pm 0.3$ & $7.51 \pm 0.1$ & $8.09 \pm 0.5$ & $7.61 \pm 0.5$ \\
\hline 3 & $7.09 \pm 0.4$ & $7.25 \pm 0.0$ & $7.13 \pm 0.3$ & $7.72 \pm 0.7$ & $7.30 \pm 0.4$ \\
\hline average & $7.21 \pm 05$ & $7.40 \pm 0.23$ & $7.32 \pm 0.29$ & $7.90 \pm 0.56$ & \\
\hline
\end{tabular}

Albumin (g/dl)

\begin{tabular}{|l|c|c|c|c|c|}
\hline 0 & $5.22 \pm 0.1$ & $5.22 \pm 0.3$ & $5.30 \pm 0.1$ & $5.53 \pm 0.2$ & $5.32 \pm 0.2^{\mathrm{a}}$ \\
\hline 3 & $4.92 \pm 0.4$ & $5.04 \pm 0.3$ & $5.15 \pm 0.3$ & $5.06 \pm 0.5$ & $5.04 \pm 0.3^{\mathrm{b}}$ \\
\hline average & $5.07 \pm 0.3$ & $5.13 \pm 0.27$ & $5.23 \pm 0.25$ & $5.29 \pm 0.41$ & \\
\hline \multicolumn{4}{|l|}{ Globulin (g/dl) }
\end{tabular}

\begin{tabular}{|l|l|l|l|l|l|}
\hline 0 & $2.11 \pm 0.7$ & $2.31 \pm 0.2$ & $2.20 \pm 0.1$ & $2.56 \pm 0.3$ & $2.30 \pm 0.4$ \\
\hline 3 & $2.17 \pm 0.1$ & $2.21 \pm 0.2$ & $1.98 \pm 0.6$ & $2.66 \pm 0.2$ & $2.25 \pm 0.4$ \\
\hline average & $2.14 \pm 0.4$ & $2.26 \pm 0.2$ & $2.09 \pm 0.4$ & $2.61 \pm 0.2$ & \\
\hline
\end{tabular}

\section{Albumin/Globulin ratio}

\begin{tabular}{|l|c|c|c|c|c|}
\hline 0 & $2.64 \pm 0.9$ & $2.28 \pm 0.3$ & $2.41 \pm 0.1$ & $2.17 \pm 0.2$ & $2.37 \pm 0.5$ \\
\hline 3 & $2.27 \pm 0.2$ & $2.30 \pm 0.3$ & $2.76 \pm 0.8$ & $1.90 \pm 0.1$ & $2.31 \pm 0.5$ \\
\hline average & $2.46 \pm 0.6$ & $2.29 \pm 0.3$ & $2.58 \pm 0.6$ & $2.03 \pm 0.2$ & \\
\hline Crea
\end{tabular}

Creatinine (mg/dl)

\begin{tabular}{|l|c|c|c|c|c|}
\hline 0 & $1.60 \pm 0.2$ & $2.33 \pm 0.4$ & $1.70 \pm 0.7$ & $1.47 \pm 0.1$ & $1.78 \pm 0.5$ \\
\hline 3 & $1.30 \pm 0.2$ & $1.63 \pm 0.4$ & $1.50 \pm 0.1$ & $1.57 \pm 0.3$ & $1.50 \pm 0.3$ \\
\hline average & $1.45 \pm 0.2$ & $1.98 \pm 0.5$ & $1.60 \pm 0.5$ & $1.52 \pm 0.2$ & \\
\hline Activity of AST (U/I) \\
\hline 0 & $121.3 \pm 22$ & $98.3 \pm 16$ & $111.0 \pm 2$ & $130.7 \pm 28$ & $115.3 \pm 21$ \\
\hline 3 & $103.0 \pm 24$ & $116.3 \pm 6$ & $124.3 \pm 16$ & $130.7 \pm 24$ & $118.6 \pm 20$ \\
\hline average & $112.2 \pm 23$ & $107.3 \pm 15$ & $117.7 \pm 13$ & $130.7 \pm 24$ & \\
\hline Activity of ALT (U/I) \\
\hline 0 & $15.0 \pm 11$ & $19.0 \pm 7.0$ & $26.7 \pm 9.8$ & $23.3 \pm 7.1$ & $21.0 \pm 8.9$ \\
\hline 3 & $14.3 \pm 10$ & $24.3 \pm 2.5$ & $32.7 \pm 3.2$ & $25.3 \pm 3.5$ & $24.2 \pm 8.4$ \\
\hline average & $14.7 \pm 9.5^{\mathrm{b}}$ & $21.7 \pm 5.5^{\text {ab }}$ & $29.7 \pm 7.3^{\mathrm{a}}$ & $24.3 \pm 5.1^{\mathrm{a}}$ & \\
\hline
\end{tabular}

* Means within each row or within each column within each trait having similar letter are not significantly different at $P \geq 0.05$.

Overall mean of creatinine concentration was $1.98,1.60,1.52$ and 1.45 $\mathrm{mg} / \mathrm{dl}$ in T2, T3, T4 and T1, respectively, which were within the normal range $(0.9-2.0 \mathrm{mg} / \mathrm{dl})$ given by Jawasreh et al. (2010) with sheep.

An increased AST activity in lambs fed 15 and 20\% DDGS and decreased activity in lambs fed 10\% DDGS was observed as compared to the control treatment. Only inclusion of DDGS in diets of lambs at levels of 15 or $20 \%$ led to gradual increase in AST activity, being more pronounced with the highest DDGS level. The overall mean of ALT activity showed significant $(P<0.05)$ increase in lambs fed 15 and 20\% DDGS and insignificant increase in lambs fed $10 \%$ DDGS as compared to the control treatment.

In comparison with the present results, Saleh et al. (2008) reported marked increase in AST activity in blood serum of lambs fed 10 and $20 \%$ corn gluten feed (CGF)-contained rations compared to the control, but this increase was significant. 
The lambs of $\mathrm{T} 1$ and $\mathrm{T} 2$ recorded nearly similar values of average daily gain (ADG), however, those of T3 and T4 had higher ADG than the control by about 11.0 and $17.7 \%$, respectively (Table 6 ).

Table 6: Daily gain, feed intake and feed conversion, feed cost ( $L E / \mathrm{kg}$ gain) and economic efficiency (\%) as affected by DDGS level in the diet of lambs at 0-24 weeks post feeding.

\begin{tabular}{|c|c|c|c|c|}
\hline \multirow{2}{*}{ Traits } & \multicolumn{4}{|c|}{ Experimental diets } \\
\hline & T1 & T2 & T3 & T4 \\
\hline Initial wt. kg & $17.6 \pm 4.1$ & $17.8 \pm 3.9$ & $17.7 \pm 2.3$ & $17.6 \pm 2.4$ \\
\hline Final wt. kg & $45.2 \pm 5.2$ & $44.9 \pm 6.4$ & $48.0 \pm 6.2$ & $50.3 \pm 3.1$ \\
\hline ADG, g & $163.1 \pm 15.7$ & $161.3 \pm 20.1$ & $181.0 \pm 28.3$ & $192.0 \pm 9.3$ \\
\hline \multicolumn{5}{|l|}{ Feed intake: } \\
\hline DMI : $\quad \mathrm{g} / \mathrm{h} / \mathrm{d}$ & 1198.7 & 1180.6 & 1230.0 & 1278.1 \\
\hline $\mathrm{g} / \mathrm{kg} \mathrm{BW}^{0.15}$ & 90.40 & 89.10 & 89.65 & 94.70 \\
\hline TDNI $\mathrm{g} / \mathrm{h} / \mathrm{d}$ & 799.5 & 857.1 & 895.4 & 954.7 \\
\hline $\mathrm{g} / \mathrm{kg} \mathrm{BW}^{0.15}$ & 60.3 & 64.7 & 65.3 & 70.8 \\
\hline DCPI : g/h/d & 131.73 & 145.92 & 147.11 & 161.68 \\
\hline $\mathrm{g}^{\mathrm{kg} \mathrm{BW}} \mathrm{kW}^{0.15}$ & 9.93 & 11.01 & 10.72 & 11.99 \\
\hline \multicolumn{5}{|c|}{ Feed conversion: } \\
\hline g DM/g gain & 7.35 & 7.32 & 6.80 & 6.66 \\
\hline g TDN/g gain & 4.90 & 5.31 & 4.95 & 4.97 \\
\hline g DCP/g gain & 0.81 & 0.90 & 0.81 & 0.84 \\
\hline \multicolumn{5}{|c|}{ Price of daily gain*: } \\
\hline$(L E)$ & 3.26 & 3.23 & 3.62 & 3.84 \\
\hline \multicolumn{5}{|l|}{ Feed price ${ }^{\star \star}$ : } \\
\hline$(L E / \mathrm{kg})$ & 1.62 & 1.56 & 1.54 & 1.51 \\
\hline \multicolumn{5}{|l|}{ Daily feed cost: } \\
\hline$L E$ & 1.94 & 1.84 & 1.89 & 1.93 \\
\hline \multicolumn{5}{|c|}{ Economic efficiency: } \\
\hline$\%$ & 68.0 & 75.5 & 91.5 & 99.0 \\
\hline$\%$ of control & 100.0 & 111.0 & 134.6 & 145.6 \\
\hline
\end{tabular}

* Price of one kg live BW was considered 20 LE.

** Feed price was calculated based on the average price of all ingredients throughout the complete experimental period taking in the account the price changes.

The lambs fed $20 \%$ DDGS (T4) had the highest values of DMI, TDNI and DCPI $\left(\mathrm{g} / \mathrm{h} / \mathrm{d}\right.$ and $\left.\mathrm{g} / \mathrm{kg} \mathrm{BW} \mathrm{BW}^{0.75}\right)$. It was generally observed that TDNI and DCPI were gradually increased with elevating DDGS level in the diet from 0 up to $20 \%$. The DDGS inclusion in lamb diets did not show positive effects concerning feed conversion as $\mathrm{g}$ TDN or $\mathrm{g}$ DCP/g gain, meanwhile, the lambs of T3 and T4 recorded better values of DM conversion than the control (T1) by about 7.1 and $9.8 \%$, respectively.

Drouillard et al. (1999) evaluated the differences in growth performance of steers when fed diets (60\% concentrates: $40 \%$ roughage) containing dry rolled corn (51.62\%) and DDGS (53.36\%). The ADG also was marginally higher for cattle fed the DDGS, but feed efficiency was not greatly different between them. During the growing phase, Trenkle (2004) observed that increasing DDGS level tended to linearly increase ADG. Similar results have been reported by Hutchens et al. (2006). Also, Schauer et al. (2005) 
Gabr, A.A. et al.

incorporated DDGS at levels up to $15 \%$ of the total diet and Hules et al. (2006) substituted up to $22.9 \%$ of the finishing diet with DDGS and found no differences in lamb performance.

Although the feed price $(\mathrm{LE} / \mathrm{kg})$ was gradually decreased with increasing DDGS level in the diet, the daily feed cost (LE) did not obviously changed except with T4 where it decreased by about 5.2\%. Concerning economic efficiency, it was gradually improved with elevating DDGS level in the diet instead of corn and SBM where it was better for T2, T3 and T4 groups than the control (T1) by about $11.0,34.6$ and $45.6 \%$, respectively (Table 6).

Hutchens et al. (2006) reported that goats fed either a commercial or DDGS-based by-product ration gained similarly during 56-day trial. Because the by-product-based rations cost was much less than the commercial ration, returns were increased by $15.8 \%$ and $10.7 \%$ for the $20 \%$ and $30 \%$ DDGS rations, respectively compared to the commercial ration. They showed that using DDGS-based ration would increase producer profitability when feeding growing and finishing goat kids. Likewise, Stalker et al. (2006) when replaced totally dry rolled corn (DRC) and SBM in steers' diet with DDG found that, the total cost ( $\$ /$ head) was decreased by about $40 \%$ with DDG diet than the control. Recent research indicates that sheep can be fed at higher levels of DDGS than that previously considered optimal without affecting carcass characteristics (Schauer et al., 2008). This provides an opportunity for increase utilization of dried distillers' grains plus soluble in lamb finishing rations, potentially resulting in cheaper feed costs for lamb finishers (Neville et al., 2009).

From all the obtained results, it may be concluded that in general, the inclusion of DDGS instead of corn and SBM at any level ranging from 10 to $20 \%$ of CFM DM resulted in better performance, feed utilization and economic efficiency. Therefore, the lamb keepers can be advised to include DDGS in lamb diets throughout the growing and finishing phases at $20 \%$ of DM to obtain better results and more net return.

\section{REFERENCES}

Abbott, K.A. and V.M.C. Maxwell (2002). Sheep Health and Production (Handbook). University of Sydney, 2002.

A.O.A.C. (1990). Association of Official Analytical Chemists: Official Methods of Analysis. $13^{\text {th }}$ ed. Washington, D.C. USA.

Armstrong, W.D. and C.W, Carr (1964). Physiological Chemistry: Laboratory Direction, $3^{\text {rd }}$ ed., P. 75, Burges Publishing Co. Minneapolis, Minnesota.

Bartels, H. (1971). A colorimetric method for creatinine estimation. J. Clin. Chem. Acta., 32:81.

Calsamiglia, S.; M.D. Stern and J.L. Firkins (1995). Effects of protein sources on nitrogen metabolism in continuous culture and intestinal digestion in vitro. J. anim. Sci., 73:1819. 
Conway, E.J. (1962). Microdefusion Analysis Volumetric Error. 5th Ed., Crosky Lookwood and Sons Ltd., London.

Doumas, B; W. Wabson and H. Biggs (1971). Albumin Standards and measurement of serum with bromochresol green. J. Clin. Chem. Acta., $31: 87$.

Drouillard, J.S.; S.E. Ives; D.W. Anderson and R.H. Wessels (1999). Comparative value of dry-rolled corn, distiller's grains and wheat middlings for receiving diets. Cattlemen's Day, 1999: 81 - 83 .

Duncan, D. (1955). Multiple Range and Multiple F Test. Biometrics, 11: 1-42.

El-Ashry, M.A., N.E. El-Bordeny; H.M. Khattab; H.M. El-Sayed (1996). Effect dietary supplemented with medicinal herbs on nutrient digestibility and some metabolites of buffalo calves. Egypt. J. Nutrition and Feeds, 9 (2): 179.

Gabr, A.A., Kh. El. Sherif and A.F. Naeem (2008). Effect of inclusion dried distillers grains with solubles with enzyme addition in rabbit diets on performance, digestibility, carcass traits and some blood constituents. J. Agric. Sci. Mansoura Univ., 33 (9): 6335 - 6349.

Goering, H.K. and P.J Van Soest (1970). Forage Fiber Analysis (Apparatus, Reagents, Procedures and Some Applications). Agriculture Handbook No. 379, ARS-USDA, Washington, D.C., USA.

Hules, T.J.; J. Bartosh; J.A. Daniel; R.D. Zelinsky; J.E. Held and A.E. WertzLutz (2006). Efficacy of dried distillers grains with solubles as a replacement for soybean meal and a portion of corn in a finishing diet. Sheep and Goat Research J. , 21: 30-34.

Hutchens, T.K.; C. Smith; J. Johnes; K. Andries and P. Scharko (2006). Evaluation of distillers dried grains with solubles, soybean hulls and whole corn in diets for growing and finishing meat goats. University of Kentucky, Coop. Ext. Serv., July 2006 (www.uky.edu/Ag/AnimalSciences/goats/goat.html).

Jawasreh, K., F. Awawdeh, Z. Bani Ismail, O. Al-Rawashdeh and A. Al-Majali (2010). Normal hematology and selected serum biochemical values in different genetic lines of Awassi ewes in Jordan. The Internet Journal of Veterinary Medicine, $7: 2$.

Kaneko, J.J. (1989). Clinical Chemistry of Domestic Animals. $4^{\text {th }}$ Ed., Academic Press, Inc., 886 - 891.

Kazemi, A.; A.M. Tahmasbi, R. Valizadeh, M. Danesh Mesgaran and A.A. Naserian (2009). Effect of ensiled barley distillers' grains for Holstein dairy cows. J. Animal and Veterinary Advances, 8: 807-813.

Lardy, G.P. (2003). Feeding co products of the ethanol industry to beef cattle. North Dakota State University Extension Bull. AS-1242. North Dakota State University, Fargo.

Leupp, J.L. (2008). Use of corn distillers dried grains in beef cattle diets. Ph.D. Thesis, Fac. of the North Dakota State University of Agriculture and Applied Science.

Leupp, J.L., G.P. Lardy and J.S. Caton (2006). Effects of increasing levels of distillers dried grains plus soluble to steers offered moderate-quality forage. 2006 Beef Report: 3-5 pp., North Dakota State University Fargo, N.D. 
Gabr, A.A. et al.

Leupp, J.L., G.P. Lardy, K.K. Karges, M.L. Gibson and J.S. Caton (2009). Effects of increasing level of corn distillers dried grains with solubles on intake, digestion, and ruminal fermentation in steers fed seventy percent concentrate diets. J. Anim. Sci., 87 (9): 2906-2912.

MAFF (1975). Ministry of Agriculture, Fisheries and Food. Energy Allowances and Feeding Systems for Ruminants. Technical Bulletin 33 London, H.M. 50.

McEachern, J. (2008). The effect of feeding distiller's dried grains to market lambs on performance and carcass characteristics. M.Sc. Thesis, Fac. of the Graduate School of Angelo State University.

May, M. L. 2008. The effects of grain processing method, wet and dry distiller's grains with solubles and roughage level on performance and carcass characteristics of finishing cattle. M.Sc. Thesis, Kansas State Univ., Manhattan.

May, M.L.; J.S. Drouillard; M.J. Quinn and C.E. Walker (2007). Wet distiller's grains with solubles in beef finishing diets comprised of steam-flacked or dry-rolled corn. Beef Cattle Research- 2007, Report of Progress, 978: $57-59$.

NASS (2008). National Agricultural Statistics Service. http://www.nass.usda.gov/QuickStats/indexbysubject.jsp?

Neville, B.W., C.S. Schauer, M.M. Thompson, P.B. Berg, and G.P. Lardy (2009). Influence of thiamin supplementation on feedlot performance and carcass quality of lambs fed a $60 \%$ distillersdried grains plus solubles finishing rations. Sheep Research Report, 5: 5-10.

Noll, S. (2008). Update-Utilization of feed. Byproducts of the biofuels industry in turkey diets. (http://www.ddgs.umn.edu/ppt-poultry/2008-Noll-\%20 Update-utilization\%20of\%20feed\%20byproducts.

NRC. 1985. Nutrient Requirements of Sheep (6th Rev. Ed.). National Academy Press, Washington, DC.

NRC (1998). Nutrient Requirements of Swine. $10^{\text {th }}$ ed., National Academy Press, Washington, D.C., USA.

NRC (2001). Nutrient Requirements of Dairy Cattle. 7th rev. ed. Natl. Acad. Sci., Washington, DC.

Pederson, C, M.G Boersma, and H.H. Stein (2007). Digestibility of energy and phosphorus in ten samples of distillers dried grains with solubles fed to growing pigs. J. Anim. Sci., 85: 1168-1176.

Reitman, S. and S. Frankel (1957). Colorimetric determination of serum glutamic oxaloacetic and glutamic pyruvic transaminases. Amer. J. Clin. Path., 28:56.

Saleh, S.A., M.M. Mustafa and M.K.I. Kottb (2008). Effect of using corn gluten feed in growing lambs ration. Egypt. J. Nutrition and Feeds, 11 (1): 5571.

SAS (2000). SAS user's Guide Statistics Version 9.1., SAS Institute Inc., Cary, N.C., USA.

Schauer, C.S.; M.M. Stamm; T.D. Maddock and P.B. Berg (2008). Feeding of DDGS in lamb Rations. Sheep and Goat Research J. 23: 15-19. 
Schauer, C.S.; L.P. Anderson; D.M. Stecher; D. Pearson and D. Drolc (2005). Influence of dried distillers grains on feedlot performance and carcass characteristics of finishing lambs. Western Dakota Sheep \& Beef Day, 46: $31-33$

Schwartzkopf-Genswein, K.S., Beauchemin, K.A., Gibb, D.J., Crews Jr., D.H., Hickman, D.D., Streeter, M., McAllister, T.A. (2003). Effect of bunk management on feeding behavior, ruminal acidosis and performance of feedlot cattle: a review. J. Anim. Sci., 81: E149-158E.

Spiehs, M.J.; M.H. Whitney and G.C. Shurson (2002). Nutrient database for distillers dried grains with solubles produced from new ethanol plants in Minnesota and South Dakota. J. Animal Science 80: 2639.

Stock, R.A., J.M. Lewis, T.J. Klopfenstein, and C.T. Milton (2000). Review of new information on the use of wet and dry milling feed by-products in feedlot diets. J. Anim. Sci. Available:

http://www. asas.org/ symposia/ proceedings/ 0924.pdf. Accessed: Jan. 14, 2006.

Stalker, L.A.; D.C. Adams and T.J. Klopfenstein (2006). Influence of dried distillers grains supplementation frequency on forage digestibility and growth performance. Nebrasca Beef Cattle Reports (2006): 33-35.

Trenkle, A. (2004). Evaluation of wet and dry distillers grains with solubles for finishing Holstein steers. Pages 1-7 in lowa Animal Industry Report. A.S. Leaflet R1883. lowa State Univ., Ames.

Warner, A.C.J. (1964). Production of volatile fatty acids in the rumen methods of measurements. Nutr. Abst. And Rev., 34:339.

Yousef, H.F.H.( 2005 ). Nutritional and physiological studies in small ruminants , Ph. D . Thesis, Faculty of Agriculture ,Mansoura university.

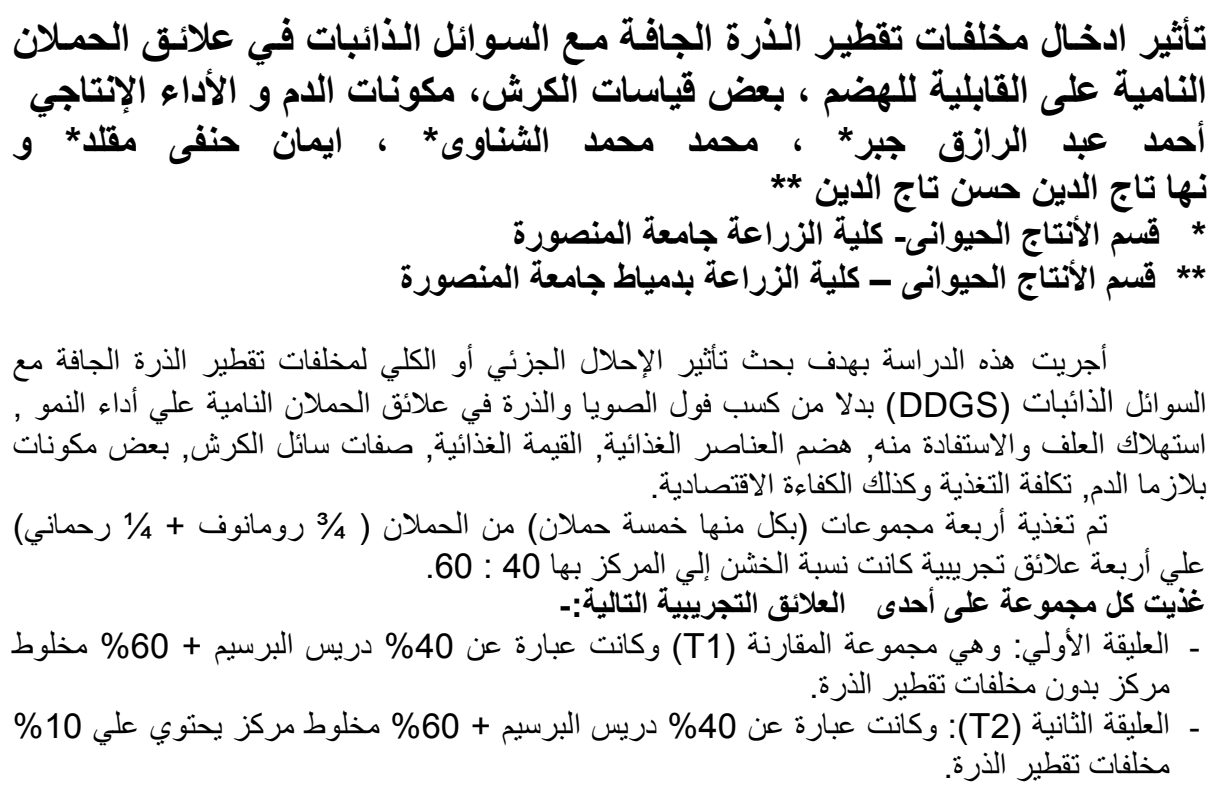


Gabr, A.A. et al.

- العليقة الثالثة (T3): وكانت عبارة عن 40\% دريس البرسيم + 60\% مخلوط مركز يحتوي علي 15\%

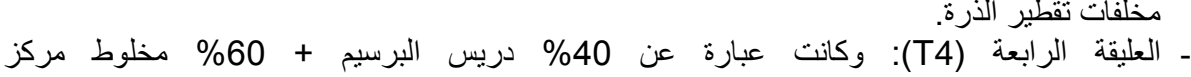
يحتوي علي 20\% مخلفات تقطير الذرة.

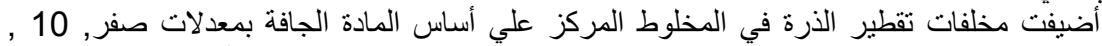

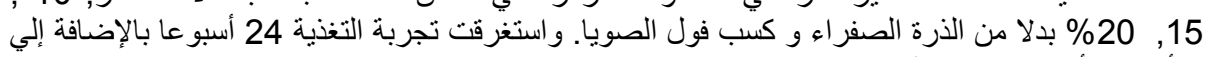

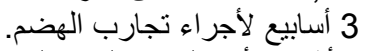
و أثشارت أهم النتائج الي مايلي:

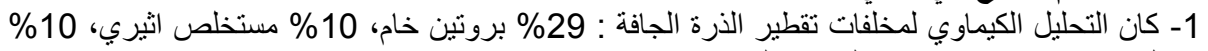

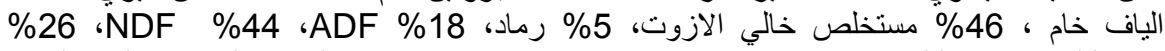

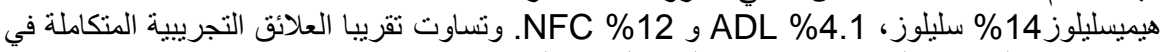

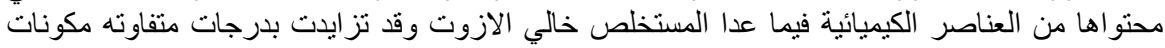

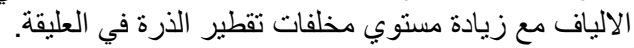

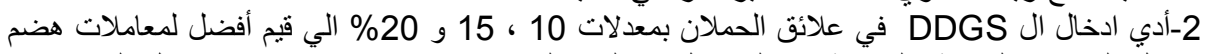

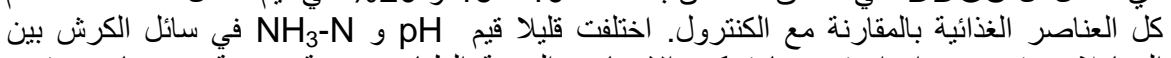

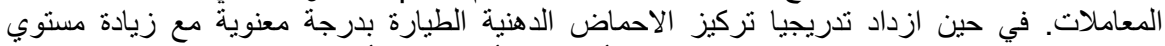

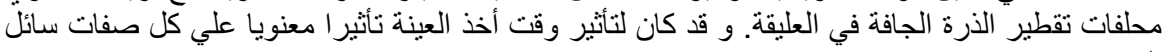

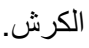

3- ازدادت تدريجيا قيم

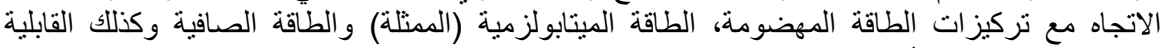

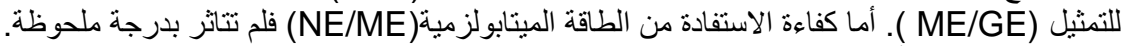

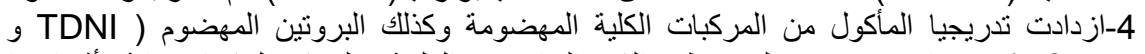

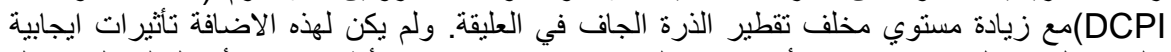

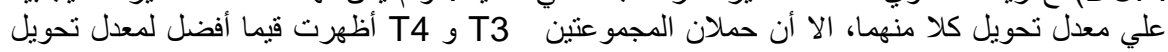

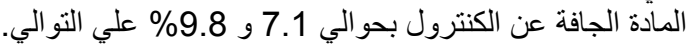

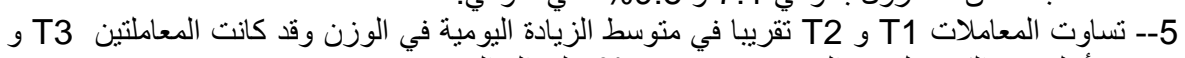

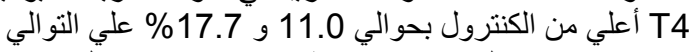

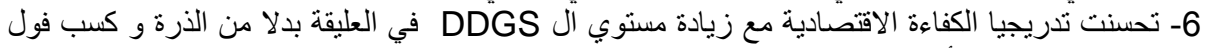

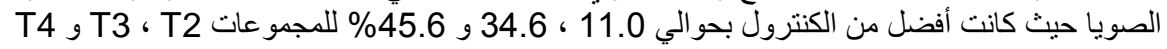

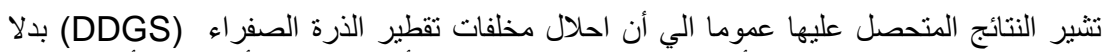

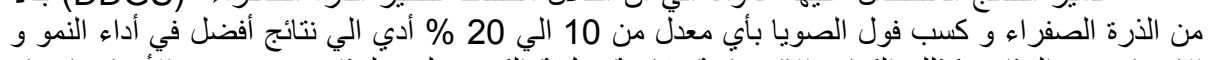

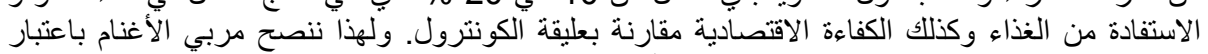

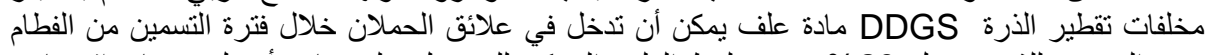
أحتي التسويق للذبح بمعدل 20\% من مخلوط العلف المركز للحصول علي نتائج أفضل و عائد اقتصادي

كلية الزراعة - جامعة المنصورة كلية الزراعة - جامعة شبين الكومة الكورم

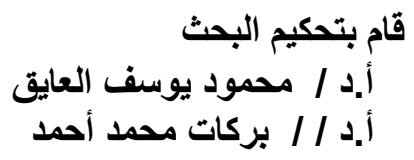

